\title{
SCLERODERMA IN MALES AND FEMALES: A COMPARATIVE STUDY IN A BRAZILIAN SAMPLE
}

Kamilla de Bessa Jorge ${ }^{1, \star}$, Laís Zanlorenzi ${ }^{1}$, Matheus Renato Costa $^{1}$, Igor Zammar Jorge ${ }^{1}$, Renato Nisihara, Patrícia Martin ${ }^{1}$, Thelma Larocca Skare ${ }^{1}$

1.Hospital Universitário Evangélico Mackenzie, Curitiba (PR), Brazil.

*Corresponding author: kamillabessajorge@gmail.com

\section{BACKGROUND}

Systemic sclerosis (SSc) is a disease with female preponderance suggesting that gender may modulate the disease expression. Estradiol has been considered to have profibrotic effects, and postmenopausal females with diffuse SSc have significantly higher levels of serum estrogens compared to age-matched healthy controls suggesting that this hormone may modulate the disease. The aim of this study was to compare the clinical and serological findings in males and females with scleroderma.

\section{METHODS}

Retrospective study of 215 SSc patients with epidemiological (age, age at disease onset, tobacco exposure, and ethnic background), clinical data (scleroderma subset; cardiovascular, respiratory, renal and digestive system; skin and subcutaneous tissue), autoantibodies profile (antinuclear antibodies or ANA, anti-Scl-70 and anticentromere) were obtained through charts review. The presence of organ involvement was considered in a cumulative way and classified according to ACR definition. Disease duration was considered from the first symptom not Raynaud's phenomena. The skin involvement was measured by the modified Rodnan (Rodnan $\mathrm{m}$ ) index and disease severity was evaluated by the Medsger scale.

\section{RESULTS}

In this sample 22/215 (10.2\%) were male and 193/215 (89.7\%) were female with a proportion female:male of 8.7:1. The female sample, had same disease duration than the male $(p=0.21)$. Females had more esophageal involvement $(p=0.003)$, telangiectasias $(p=0.03)$ and antinuclear antibodies (ANA) $(p=0.04)$; males had more fingertip scars $(p=0.03)$, digital ulcers $(p=0.006)$ and worse Medsger index (median values of 6 in males vs. 4 in females; $p=0.05$ ).

\section{CONCLUSION}

In the studied sample, males had more severe disease than females as well as more fingertip scars and digital ulcers. The female sample had more esophageal involvement, telangiectasias and ANA.

\section{KEYWORDS}

Scleroderma, Male, Female, Antinuclear antibodies. 